\title{
Joint meeting between the Royal College of Psychiatrists and the Czech Psychiatric Association*
}

\author{
D. D. R. Williams
}

International conferences can be compared to mediaeval pilgrimages, a view that was reinforced during this visit to Prague. A diverse group of people with a common purpose travelling to an exotic distant city.

The purpose of the visit was the Joint Conference between the Royal College of Psychiatrists and the Czech Psychiatric Association. The College was represented by its officers, staff and nearly 150 people including delegates, relatives and friends. The scientific sessions were a blend of contribution from individuals from the two organisations.

Travelling away often makes it easier to reflect on issues at home. A session which was very relevant to our Czech colleagues and ourselves, focused on the changing pattern of services. In the Czech republic the psychiatric service is based almost entirely on large mental hospitals supplemented by outpatient clinics. This was in stark contrast to the severe bed shortage crisis in London (Watson, 1994). One was surprised, and perturbed, to learn that NHS patients from Camberwell were being admitted to the Priory Hospital in Roehampton. The cycle had now been completed. After the closure policy of most of the large psychiatric hospitals around London, the Priory is beginning to provide a comparable service again! In the discussions there was a general view that two topics should be on the agenda of British psychiatrists: a realistic review of the

*Held in Prague, 3-6 November 1994. closure policy and the role of units in district general hospitals.

The scientific sessions were complemented by a visit to the opera and two receptions. The second of these was at the Wallenstein Palace. a magnificent 17th century palace in the old part of the city. At this function, the formal ties between the two organisations were consolidated by the exchange of gifts. Our Czech colleagues made presentations to three key people: Dr Fiona Caldicott, the President of the College, Dr James Birley and Dr Richard Fox. Dr Fox, like Dr Jean Harris Hendriks (Zvolsky et al, 1993), has had close contact and friendships with Czech psychiatrists over many years. Likewise the President made presentations to three Czech colleagues who had ensured the success of the meeting: Professor P. Zvolsky, President of the Czech Psychiatric Association. Professor C. Hoschl, and Professor C. Skoda.

The conference was a success. True conferring had taken place. We had sampled the rich cultural heritage of Central Europe. We were introduced to Svejk, the Good Soldier, a comparable figure to another middle European personage - who has now been integrated into psychiatry - Baron Munchausen.

\section{References}

Watson, J. P. (1994) Too few beds. Psychiatric Bulletin, 18. 531.

ZVOLSKY, P.. MALA, E. \& HARRUS HENDRIKS, J. (1993). Psychiatry as seen in Prague-Spring 1992. Psychiatric Bulletin. 17, 160-161

D. D. R. Williams, Consultant Psychiatrist, Cefn Coed Hospital, Swansea SA2 OGH 